\title{
Abdominal Drainage versus Non Drainage for Uncomplicated Laparoscopic Cholecystectomy Operations in Assiut University Hospital
}

\author{
HESHAM RIAD, M.D.; SAMER A. AMMAR, M.D. and MOHAMED Sh. ISMEAL, M.Sc. \\ The Department of General Surgery, Faculty of Medicine, Assiut University, Assiut, Egypt
}

\begin{abstract}
Background: The traditional method of routine abdominal drainage after uncomplicated laparoscopic cholesyectomy can increase wound infection rate and hospital stay.

Patients and Methods: In our study we had 40 patients with chronic calcular cholecystitis. They were randomly assigned into one of the two study groups: Group I: With drains age; Group II: Without drains age. The result calculated was to compare between the two groups mainly the time of hospital stay, early recovery and surgical complications.

Results: The mean operative time for the drain age group is $(61.8 \pm 11.8)$ per min and $(53.0 \pm 11.8)$ for the non drain age group. The mean hospital stay for the drain age group is $30.4 \pm 4.3$ (hours) and $18.8 \pm 3.8$ (hours) for the non drain age group. The mean pain scores for the drain group is $5.8 \pm 2.1$ and 3.9 \pm 1.6 for the non drain age group post-operative complications which are wound infection, fever, bile leakage occur with high rate among the drain age group, however there are no statistically significant differences between the 2 studied groups. Post-operative prolonged shoulder pain occur in one case in the non drain group.

Conclusion:

- Use of drain age in uncomplicated lap cholecystectomy didn't result in reduction of post-operative complications.

- It was also associated with prolonged operative time, higher pain score and longer hospital stay.
\end{abstract}

Key Words: Drainage versus non drainage - Uncomplicated lap cholecystectomy.

\section{Introduction}

LAPAROSCOPIC Cholecystectomy (LC) was introduced as an alternative to conventional open gallbladder removal by Mouret in 1987 and its use soon became good standard for surgical treatment of cholelithiasis and gallbladder benign polyop [1]

Correspondence to: Dr. Mohamed Sh. Ismael,

The Department of General Surgery, Faculty of Medicine, Assiut University
Despite the fact that LC is one of the most commonly performed procedures (and the issue of drainage would be considered a relatively simple one), the role of routine drainage after LC is still an issue of considerable debate.

A recent Australalin survey showed that surgeons may be divided into those who always drain after LC, those who use drainage in selected patients and those who never use it [2].

The purpose of the drainage of the hepatic bed after cholecystectomy is to avoid bile/or blood collections that might become infected thus requiring further interventional procedures, both radiological and surgical. Moreover, the drainage may let $\mathrm{CO} 2$ escape, thereby decreasing the peritoneal irritation and so post-operative shoulder pain and nausea $[3,4]$. Yet, an intra-abdominal drainage cannot always detect aneighboring fluid collectionsv and it has any not negligible risks as bowel and vessels lesions by decubitus, potential entrance site for infections and painful removal, many surgeons' state that patients has nothing to lose by having a peritoneal drain placed for $24 / \mathrm{h}$. But this may reassure the surgeon rather than patients, more over the drain might increase post-operative discomfort $[\mathbf{5 , 6}]$

\section{Patients and Methods}

The present study is a prospective randomized study. The study included 40 patients from the Surgery Department of Sohag General Hospital

\footnotetext{
Abbreviations:

ERAS : Enhanced Recovery after Surgery.

FTS : Fast Track Surgery.

ASA : American Society of Anathesiologists.

CI : Confidence Interval.

VAS : Visual Analogue Scalel.
} 
and Assiut University Hospital with chronic calcular cholecystitis in the period from April 2016 to Mars 2017. They were randomly assigned into one of the two study groups: Group I: With drains; Group II: Without drains.

The result was calculated to compare between the two groups mainly the time of hospital stay, early recovery and surgical complication.

\section{Inclusion criteria:}

Patients were selected to participate in the study if they have chronic calcular cholecystitis and eligible for laproscopic cholecystectomy.

\section{Exclusion criteria:}

- Acute cholecystitis.

- Previous major abdominal operation.

- Intra-operative complication as bleeding and biliary leakage.

- Patients who required common bile duct exploration or any other additional procedure.

- Patient refusal to laparoscopic cholecystectomy.

- Conversion to open surgery.

All participants were subjected to the following:

- Clinical examination.

- Routine laboratory investigations.

- Abdominal Ultrasonography.

- Pre-operative fittness.

- Laparoscopic cholecystectomy.

Laproscopic cholecystectomy was done in both groups by using the standard 4 port technique.

The following data were extracted from each group. Characteristics of patients (age, gender and indication to surgery), main features of the surgical procedures (operative time, type of drainage) and clinical outcome (abdominal collections, reinterventional procedures, infections, abdominal pain, hospital stay).

\section{Post-operative care:}

- Abdominal U/S was done only for to patients suspected to have collection (if they have persistant shoulder pain, fever, elevated leucocytic count or persistent vomiting).

- Parentral antibiotics were given with induction and for the first two days post-operatively.
- Wound care as per routine.

- Avoid irritant adhesive tape over the skin.

- Monitoring the quantity of drainage in group 1.

- Analgesics for the first day post-operatively.

- Removal of the drain on second post-operative day.

- Early ambulation to avoid risks of bed rest.

- Discharge.

- Removal of stitches after seven days.

The perioperative variables (operative time, post-operative pain, and post-operative hospital stay) were evaluated. We checked for post-operative pain using a Visual Analog Scale (VAS) from 0 (no pain) to 10 (worst pain imaginable) $12 \mathrm{~h}$ after the operation.

\section{Results}

\section{Personal and clinical data:}

The mean age for the study group is $56.8 \pm 8.6$ for the drain group and $58.8 \pm 7.9$ for non drain group. Male to female ratio is $6-14$ for the drain group and 5-15 for non drain group. The BMI is almost equal in both groups.

Comparison between the studied groups regarding age, BMI and sex didn't reveal statistically significant differences (Table 1).

Table (1): Personal and clinical data of the studies groups.

\begin{tabular}{lcccc}
\hline & \multirow{2}{*}{$\begin{array}{c}\text { Drain } \\
\mathrm{n}=20\end{array}$} & $\begin{array}{c}\text { No drain } \\
\mathrm{n}=20\end{array}$ & \multicolumn{2}{c}{ Student $t$-test } \\
\cline { 4 - 5 } & & & \multicolumn{1}{c}{$t$} & $p$ \\
\hline Age (years) & $56.8 \pm 8.6$ & $58.8 \pm 7.9$ & -0.73 & 0.46 \\
BMI $\left(\mathrm{Kg} / \mathrm{m}^{2}\right)$ & $30.1 \pm 4.6$ & $29.2 \pm 4.4$ & 0.59 & 0.55 \\
\hline & & & \multicolumn{2}{c}{ Chi-square test } \\
\cline { 4 - 5 } & & & $\chi^{2}$ & $p$ \\
\hline Gender: & & & \\
Male & $6(30.0 \%)$ & $5(25.0 \%)$ & 0.13 & 0.73 \\
Female & $14(40.0 \%)$ & $15(75.0 \%)$ & & \\
\hline
\end{tabular}

\section{Hospital stay:}

The mean hospital stay for the drain group is $30.4 \pm 4.3$ (hours) and $18.8 \pm 3.8$ (hours) for the non drain group. The differences are highly statistically significant $(p=0.0001)$ no mortality was reported (Table 2). 
Table (2): Hospital stay.

\begin{tabular}{|c|c|c|c|c|}
\hline & \multirow{2}{*}{$\begin{array}{l}\text { Drain } \\
\mathrm{n}=20\end{array}$} & \multirow{2}{*}{$\begin{array}{c}\text { No drain } \\
n=20\end{array}$} & \multicolumn{2}{|c|}{ Student $t$-test } \\
\hline & & & $t$ & $p$ \\
\hline \multirow[t]{3}{*}{$\begin{array}{l}\text { - Hospital stay } \\
\text { per gour }\end{array}$} & $\begin{array}{l}30.4 \pm 4.3 \\
\text { hour }\end{array}$ & $\begin{array}{l}18.8 \pm 3.8 \\
\text { hour }\end{array}$ & 8.9 & $0.0001 *$ \\
\hline & & & \multicolumn{2}{|c|}{ Chi-square test } \\
\hline & & & $x^{2}$ & $p$ \\
\hline Mortality & & & 0.0 & 1.0 \\
\hline
\end{tabular}

\section{Post-operative complications:}

Regarding the previously reported post operative complications which are wound infection, fever, bile leakage occur with high rate among the drain group, however there were no statistically significant differences between the studied groups. Post-operative prolonged shoulder pain occur in one case in the non drain group in our trial (Table 3).

Table (3): Post-operative complications.

\begin{tabular}{lcccc}
\hline & \multirow{2}{*}{$\begin{array}{c}\text { Drain } \\
\mathrm{n}=20\end{array}$} & $\begin{array}{c}\text { No drain } \\
\mathrm{n}=20\end{array}$ & \multicolumn{2}{c}{ Chi-square test } \\
\cline { 5 - 6 } & & & $\chi^{2}$ & $p$ \\
\hline - Wound infection & 2 & 1 & 2.06 & 0.15 \\
- Fever & 2 & 1 & 0.36 & 0.55 \\
- Bile leakage & 1 & 3 & 1.11 & 0.36 \\
- Perihepatic collection & 1 & - & 1.03 & 0.55 \\
- Acute pancreatitis & & 1 & 1.03 & 0.31 \\
- Post-operative & & & & \\
prolonged shoulder pain & & & 1.56 & 0.21 \\
- Nausea and vomiting & 2 & 5 & &
\end{tabular}

\section{Post-operative pain:}

The mean pain scores for the drain group is $5.8 \pm 2.1$ and $3.9 \pm 1.6$ for the non drain group.

The difference is highly significant $(p=0.003)$, (Table 4).

Table (4): Pain score (visual analogue scale).

\begin{tabular}{lcccc}
\hline & \multirow{2}{*}{$\begin{array}{c}\text { Drain } \\
\mathrm{n}=20\end{array}$} & $\begin{array}{c}\text { No drain } \\
\mathrm{n}=20\end{array}$ & \multicolumn{2}{c}{ Student $t$-test } \\
\cline { 4 - 5 } & & & $t$ & $p$ \\
\hline Pain score (VAS) & $5.8 \pm 2.1$ & $3.9 \pm 1.6$ & 3.11 & $0.003^{*}$ \\
\hline & & & \multicolumn{2}{c}{ Chi-square test } \\
\cline { 4 - 5 } & & & $\chi^{2}$ & $p$ \\
\hline $\begin{array}{l}\text { Pain grade: } \\
\begin{array}{l}\text { Mild } \\
\text { Moderate-severe }\end{array}\end{array}$ & 14 & 6 & 6.4 & $0.011^{*}$ \\
\hline
\end{tabular}

\section{Operative time:}

The mean operative time for the drain group was $(61.8 \pm 11.8)$ per min and $(53.0 \pm 11.8)$ for the non drain group. The operative time was longer for the drain group in comparison to the non drain group. The difference was highly statistically significant $(p=0.024)$ (Table 5).

Table (5): Operative time.

\begin{tabular}{|c|c|c|c|}
\hline $\begin{array}{l}\text { Drain } \\
n=20\end{array}$ & \multirow{2}{*}{$\begin{array}{l}\text { No drain } \\
n=20\end{array}$} & \multicolumn{2}{|c|}{$\begin{array}{c}\text { Student } \\
t \text {-test }\end{array}$} \\
\hline & & $t$ & $p$ \\
\hline \multicolumn{4}{|c|}{ Operative time (min.) $61.8 \pm 11.853 .0 \pm 11.82 .2$} \\
\hline & \multicolumn{3}{|c|}{ Chi-square tes } \\
\hline & $x^{2}$ & & $p$ \\
\hline
\end{tabular}

\section{Discussion}

Laparoscopic cholecystectomy provides a safe and effective treatment for patients with gallstones as it reduces post-operative pain with almost invisible scar, short hospital stay and earlier return to work [4].

On the other side, many patients complain of abdominal pain, shoulder tip pain, and nausea/ vomiting post-operatively [7]. High pressure pneumoperitoneum using carbon dioxide gas was accused for those complications. Thus, a drainage tube is inserted [8]

The value of surgical drainage in open cholecystectomy is an issue that is not resolved till now [7]. The same in laparoscopic cholecystectomy, where the lack of evidence on usefulness of drain age is present. Again surgeons keep being divided among those placing a drain selectively, and those who never place a drain, based on their personal experience, beliefs, or bias [5]

The present study recruited 40 patients indicated for laparoscopic cholecystectomy. They were equally and randomly assigned into one of two groups: Group 1 that had post-operative drain and group 2 that had no drain.

Demographic and clinical characteristics in this study:

The mean age for the study group was $56.8 \pm 8.6$ for the drain group and 58.8 \pm 7.9 for non drain group.

Male to female ratio was 6-14 for the drain group and 5-15 for non drain group. 
The BMI was almost equal in both groups.

Comparison between the studied groups regarding age, BMI and sex didn't reveal statistically significant differences.

\section{Analysis of the operative time:}

The mean operative time for the drain group was $(61.8 \pm 11.8)$ per min and $(53.0 \pm 11.8)$ for the non drain group.

The operative time was longer for the drain group in comparison to the non drain group. The difference is highly statistically significant $(p=$ $0.024)$.

This is in harmony with the study of El-Labban et al., [8]

In the study of Kim et al., [9], patients were randomly assigned to undergo drain insertion (94 patients, 48.7\%, Group A) or not (99 patients, $51.3 \%$, Group B). In 18 cases (9.3\%), post operative morbidities such as bleeding, bile leakage, wound infection or an abscess occurred, and there was no significant difference between the two groups.

\section{Assessment of pain:}

Pain was scored on the visual analogue scale of 0 to 10 . The mean pain scores for the drain group is $5.8 \pm 2.1$ and $3.9 \pm 1.6$ for the non drain group.

The difference is highly statistically significant $(p=0.003)$, in our study, patients in the drain group had significantly higher pain scores and higher frequency of moderate-severe pain states when compared with patients without drain.

\section{Hospital stay:}

The mean hospital stay for the drain group was $30.4 \pm 4.3$ (hours) and $18.8 \pm 3.8$ (hours) for the non drain group. The differences are highly statistically significant $(p=0.0001)$.

We noted that patients in the drain group had significantly longer hospital stay when compared with compared with patients in the other group. No mortality was reported.
This is in agreement with the study of Georgiou et al., [5]

\section{Conflicts of interest:}

No conflict of interest has been declared.

\section{References}

1- CUSCHIERI A., DUBOIS F., MOUIEL J., MOURET P., BECKER H., BUESS G., et al.: The European experience with laparoscopic cholecystectomy. Am. J. Surg., 161: 385-7, 1991.

2- ASKEW J.: A survey of the current surgical treatment of gallstones in Queensland. A.N.Z. J. Surg., 75: 1086-9, 2005.

3- GURUSAMY K.S., SAMRAJ K., MULLERAT P. and DAVIDSON B.R.: Routine abdominal drainage for uncomplicated laparoscopic cholecy-stectomy. Cochrane Database Syst. Rev., (4): CD006004, 2007.

4- GURUSAMY K.S., KOTI R. and DAVIDSON B.R.: Routine abdominal drainage versus no abdominal drainage for uncomplicated laparoscopic cholecystectomy. Cochrane Database Syst. Rev., (9): CD006004, 2013.

5- GEARGIOU C., DEMETRIOU N., PALLARIS T., THEODOSOPOULOS T. and KATSOUYANNI POLYMENEAS G.: Is the routine use of drainage after elective laparoscopic cholectomy justified? A randomized trial0j laparoendose Adv. Sur. Tech. A., 21: 119-23, 2011.

6- UCHIYAMA K., TANI M., TERASAWA H., HAMA T and YAMAUE H.: Clinical significance of drainage tube insertion in laparoscopic cholecystectomy: Aprospective randomized controlled trial. J. Hepatobiliary Pancreat. Surg., 14: 551-6, 2007.

7- KIM E.Y., YOU Y.K., KIM D.G., LEE S.H., HAN J.H., PARK S.K., NA G.H. and HONG T.H.: Is a Drain Necessary Routinely After Laparoscopic Cholecystectomy for an Acutely Inflamed Gallbladder? A Retrospective Analysis of 457 Cases. J. Gastrointestinal. Surg., Jan. 17, 2014.

8- EL-LABBAN G., HOKKAM E., EL-LABBAN M., SABER A., HEISSAM K. and EL-KAMMASH S.: Laparoscopic elective cholecystectomy with and without drain: A controlled randomized trial. J. Minim. Access. Surg., Jul., 8 (3): 90-2, 2012.

9- KIM E.Y., LEE S.H., LEE J.S., YOON Y.C., PARK S.K., CHOI H.J., YOO D.D. and HONG T.H.: Is routine drain insertion after laparoscopic cholecystectomy for acute cholecystitis beneficial? A multicenter, prospective randomized controlled trial. J. Hepatobiliary Pancreat. Sci., Apr. 16, 2015. 


\section{دراسة تقييم إستخدام الدرنقه من علمهل في حالات إستئصال المرارة

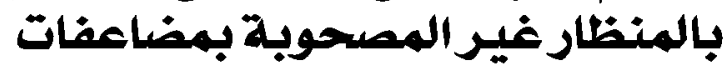

الإلتهاب المرارى المصحوب بالحصوات يوجد ب. 1:0 إ٪ من البالغين ويكون مصحوبا بآعراض ما بين 1:ع من هؤلاء البالغين كل عام. آجريت عملية إستئصال المرارة بالمنظار لآول مرة بواسطة فيليب موديت فى مدينة ليون بفرنسا فى آواخر الثمانينيات وقد لاقت عملية

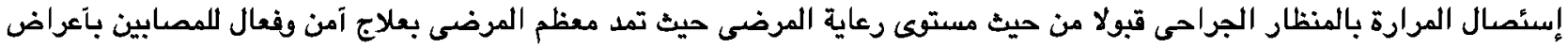
الحصوه فى المرارة.

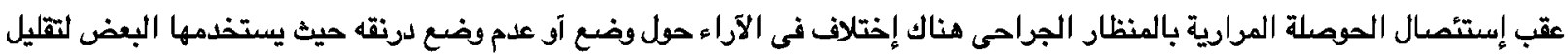

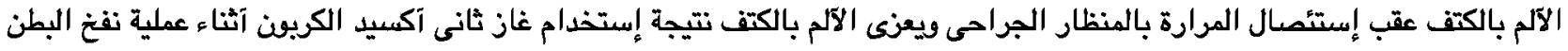

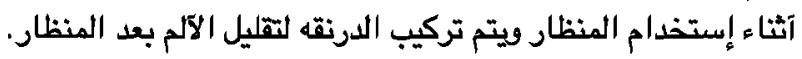

يعتقد البعض الآخر آن الإستخدام الروتيى للدرنقه آثناء إستئصال المراره بالمنظار للحالات الغير معقدة يزيد من مضاعفات العدوى ويزيد من آلام ما بعد الجراحة ويطيل من إقامة المستشفى ولا يقى من حلوث تجمعات داخل البطن البطن. تهدف هذه الدراسة إستخدام الدرنقه من عدمه فى حالات إستئصال المراره بالمنظار الغير مصحوب بمضاعفات.

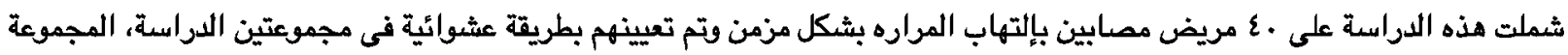

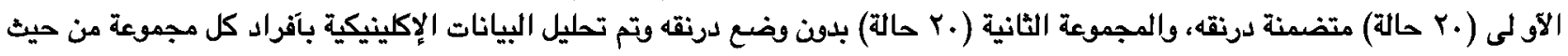
العمر والجنس ومعامل الوذن وزمن الجراحة ودرجة الآلم والمضاعفات بعد الجراحة ومدة البقاء فى المستشفى.

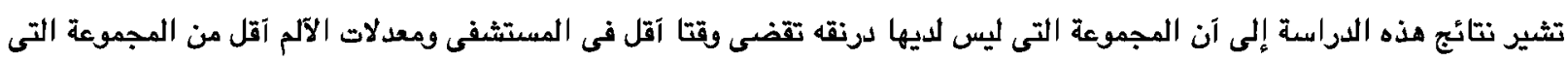
لديها درنقه كذلك وجد آن المضاعفات آكثر في المجموعة التى بها درنقه. من الواضح آن إستخدام الدرنقه فى حالات إستئصسال المراره بالهنظار الغير مصحوب بمضاعفات لا يقلل من وقت العملية ومعدل الالم 